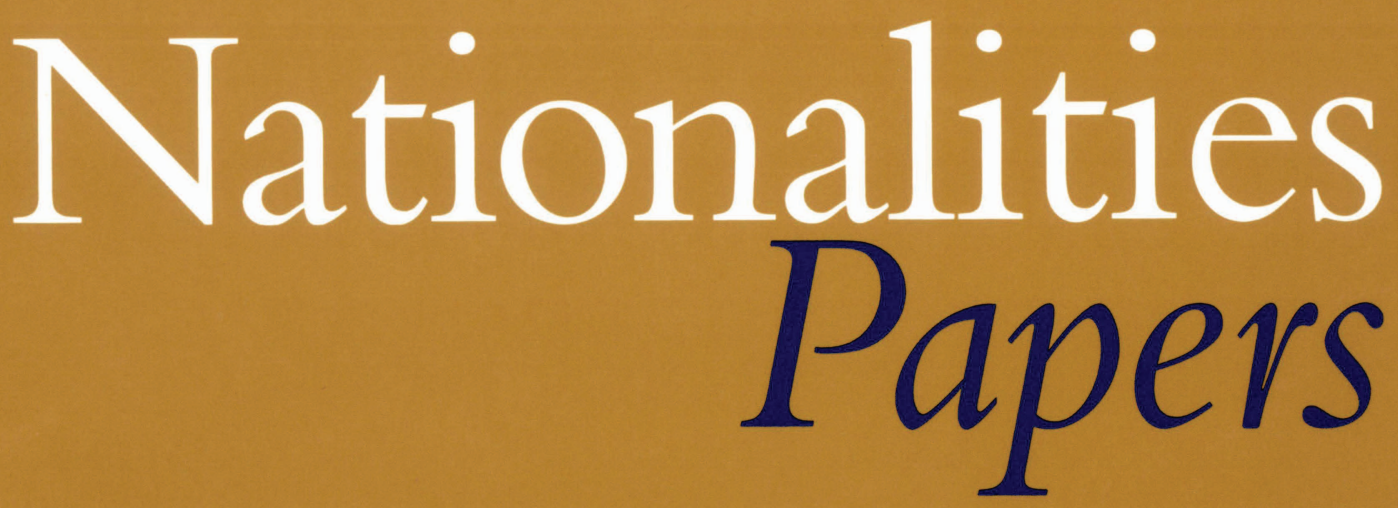

ASM ASSOCIATION FOR THE STUDY OF NATIONALITIES

\title{
Routledge
}

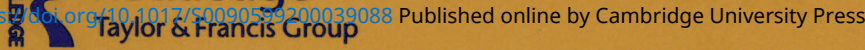




\title{
Nationalities Papers
}

\author{
EDITOR-IN-CHIEF \\ Florian Bieber, \\ University of Kent, $U K$ \\ bieberf@gmx.net
}

\author{
ASSISTANT EDITOR \\ Kristin Foster, University of North Carolina, \\ Charlotte, USA \\ BOOK REVIEW EDITOR \\ Zsuzsa Csergo, Queen's University, Canada
}

ASSOCIATE EDITORS

Dominique Arel, University of Ottawa, Canada

Gordon N Bardos, Harriman Institute, Columbia University, USA

Zsuzsa Csergo, Queen's University, Canada

Troy McGrath, Russian State University for the Humanities, Russia

Marlene Laruelle, French Centre for Russian, Caucasian, and East-European Studies, France

PAST EDITORS

Stephen Horak, Eastern Illinois University, USA (1972-1984)

Orest Subtelny, York University, Canada (1985-1986)

Henry Huttenbach, The City College of the City University of New York, USA (1987-1998)

Nancy Wingfield, Northern Illinois University, USA (1999-2002)

Steve Sabol, University of North Carolina, USA (2002-2009)

EDITORIAL BOARD

Seymour Becker, Rutgers University, USA; Stefano Bianchini, University of Bologna, Italy; Karl Cordell, University of Plymouth, UK; David Crowe, Elon University, USA; Sue Davis, Denison University, USA; Jennifer Dickinson, University of Vermont, USA; Gregory Gleason, University of New Mexico; Shale Horowitz, University of Wisconsin-Milwavkee, USA; Mark Katz, George Mason University, USA; Mills Kelly, George Mason University, USA; Jeremy King, Mt Holyoke College, USA; Ilona Klímová-Alexander, Cambridge University, UK; Marlene Laruelle, French Centre for Russian, Caucasian, and East European Studies, France; Andrew Ludanyi, Ohio Northern University, USA; David Marples, University of Alberta, Canada; Peter Mentzel, Utah State University, USA; Katherine Metzo, University of North Carolina, Charlotte, USA; Aleksandra Milicevic, University of North Florida, USA; Sebastian Peyrouse, Institute for International and Strategic Research, France; Aviel Roshwald, Georgetown University, USA; Michael Rywkin, The City College of the City University of New York, USA; Edward Schatz, University of Toronto, CA; Roland Spickermann, University of Texas, Permain Basin, USA; Stefan Wolff, University of Nottingham, UK

Editorial correspondence, including submissions to the journal, should be sent to Steven Sabol, Nationalities Papers, Department of History, The University of North Carolina at Charlotte, Charlotte, NC 28223, USA.

The editors accept no responsibility for the statements of fact or opinion made by the contributors.

Nationalities Papers receives support from the College of Arts and Sciences of the University of North Carolina at Charlotte, and from the Shevchenko Scientific Society in America.

Business correspondence, including orders and remittances relating to subscriptions, back numbers and sample copies, should be addressed to the publisher: Routledge Journals, Taylor \& Francis, Customer Services Department, Rankine Road, Basingstoke, Hants RG24 8PR, UK. Tel: +44 (0)1256 813002; Fax: +44 (0)1256 330245 .

\section{Back issues}

Taylor \& Francis retains a three-year back issue stock of journals. Older volumes are held by our official stockists: Periodicals Service Company http://www.periodicals.com/tandf.html, 11 Main Street, Germantown, NY 12526, USA, to whom all orders and enquiries should be addressed. Telephone: +1 5185374700 ; Fax: +1 518537 5899; Email: psc@periodicals.com

\footnotetext{
Abstracting and indexing services

Nationalities Papers is currently noted in Geographical Abstracts: Human Geography, Geobase, Historical Abstracts, International Bibliography of the Social Sciences (IBSS), International Political Science Abstracts, Sociological Abstracts, Zeller Verlag (IBZ/IBR) and America: History and Life.
} 


\section{Nationalities Papers}

VOLUME 37 NUMBER 5 SEPTEMBER 2009

\section{CONTENTS}

\section{ARTICLES}

Aryans or Proto-Turks? Contested Ancestors in Contemporary

Central Asia

Victor Shnirelman

Due Process in Wartime? Secret Imperial Russian Police Files on the Forced Relocation of Russian Germans during World War I Cynthia M. Vakareliyska

The Transnational Ethnic Activism of Vojvodina Hungarians Margaret Darin Hagan

"Thugs with Guns": Disaggregating "Ethnic Violence" in the Russian Federation

Richard Arnold

Narratives of Victims and Villains in Kosovo

Helena Zdravković-Zonta

The Role of Networks in Tajikistan's Civil War: Network Activation and Violence Specialists

İdil Tunçer Kılavuz

Minorities in Samarkand: A Case Study of the City's Koreans Marco Buttino

\section{BOOK REVIEWS}

Victor A. Peskin, International Justice in Rwanda and the Balkans: Virtual Trials and the Struggle for State Cooperation (Roberto Belloni)

Serhii Plokhy, The Origins of the Slavic Nations: Premodern Identities in Russia, Ukraine and Belarus (Karl Cordell)

Thomas W. Simons Jr., Eurasia's New Frontiers. Young States, Old Societies, Open Futures (Marlène Laruelle) 
Nicola Migliorino, (Re)Constructing Armenia in Lebanon and Syria:

Ethno-cultural Diversity and the State in the Aftermath of a Refugee Crisis

(Susan Pattie)

Henri Minczeles, Yves Plasseraud, and Suzanne Pourchier, Les Litvaks. L'Héritage universel d'un monde juif disparu (Michael Rywkin)

Adeeb Khalid, Islam after Communism. Religion and Politics in Central Asia

(Sébastien Peyrouse) 


\title{
Nationalities Papers
}

\author{
Subscription Information:
}

Nationalities Papers is a peer-reviewed journal, published on behalf of the Association for the Study of Nationalities by Routledge Journals, an imprint of Taylor \& Francis, an Informa business, 4 Park Square, Milton Park, Abingdon, Oxfordshire OX14 4RN, UK.

$\begin{array}{llll}\text { Annual Subscription, Volume } & \mathbf{3 7}, 2009 \\ \text { Institutional } & £ 647 & € 859 & \$ 1074 \\ \text { Online } & £ 615 & € 816 & \$ 1020 \\ \text { Personal } & £ 156 & € 204 & \$ 256 \\ \text { (Plus tax where applicable) } & \end{array}$

Subscriptions purchased at the personal rate are strictly for personal, non-commercial use only. The reselling of personal subscriptions is prohibited. Personal subscriptions must be purchased with a personal cheque or credit card. Proof of personal status may be requested.

A subscription to the institution print edition, ISSN 0090-5992, includes free access for any number of concurrent users across a local area network to the online edition, ISSN 1465-3923.

Dollar rates apply to subscribers in all countries except the UK and the Republic of Ireland where the pound sterling price applies. If you are unsure which rate applies to you please contact Customer Services in the UK. All subscriptions are payable in advance and all rates include postage. Journals are sent by air to the USA, Canada, Mexico, India, Japan and Australasia. Subscriptions are entered on an annual basis, i.e. January to December. Payment may be made by sterling cheque, dollar cheque, international money order, National Giro, or credit card (Amex, Visa, Mastercard).

For a complete and up-to-date guide to Taylor \& Francis journals and books publishing programmes, and details of advertising in our journals, visit our website: http://www.tandf.co.uk/journals

Nationalities Papers (USPS permit number 013 138) is published 6 times in January, March, May, July, September and November. The 2009 institutional subscription price is $\$ 1074$. Periodicals postage paid at Jamaica, NY, by US Mail Agent Air Business Ltd, C/O Worldnet Shipping USA Inc., 149-35 177th Street, Jamaica, New York, NY 11433.

US Postmaster: Please send address changes to cNAP, Air Business Ltd, C/O Worldnet Shipping USA Inc., 149-35 177th Street, Jamaica, New York, NY 11433.

Ordering information:

USA/Canada: Routledge Journals, Taylor \& Francis Inc., Journals Department, 325 Chestnut Street, 8th Floor, Philadelphia, PA 19106, USA. UK/Europe/Rest of World: Routledge Journals, T\&F Customer Services, T\&F Informa UK Ltd, Sheepen Place, Colchester, Essex, CO3 3LP, UK.

Advertising enquiries to:

USA/Canada: The Advertising Manager, Taylor \& Francis Inc., 325 Chestnut Street, 8th Floor, Philadelphia, PA 19106, USA. Tel: + 1 (800) 354 1420. Fax: + 1 (215) 625 2940. UK/Europe/RoW: The Advertising Manager, Taylor \& Francis, 4 Park Square, Milton Park, Abingdon, Oxfordshire OX14 4RN, UK. Tel: +44 (0)207 017 6000. Fax: +44 (0)207 0176336.

The print edition of this journal is typeset by Techset Composition Ltd, Wiltshire, and printed by Henry Ling Ltd, Dorchester, UK.

Copyright $(2009$ Association for the Study of Nationalities. All rights reserved. No part of this publication may be reproduced, stored, transmitted, or disseminated, in any form, or by any means, without prior written permission from Taylor \& Francis, to whom all requests to reproduce copyright material should be directed, in writing.

The Society (Association for the Study of Nationalities) and Taylor \& Francis makes every effort to ensure the accuracy of all the information (the "Content") contained in its publications. However, the society and Taylor \& Francis and its agents and licensors make no representations or warranties whatsoever as to the acruacy, completeness or suitability for any purpose of the Content and disclaim all such representations and warranties whether expressed or implied to the maximum extent permitted by law. Any views expressed in this publication are the views of the authors and are not the views of the Society and Taylor \& Francis.

Taylor \& Francis grants authorization for individuals to photocopy material for private research use, on the sole basis that requests for such use are referred directly to the requestor's local Reproduction Rights Organization (RRO). In order to contact your local RRO, please contact International Federation of Reproduction Rights Organizations (IFRRO), rue du Prince Royal, 87, B-1050 Brussels, Belgium; e-mail: IFRRO@skynet.be; Copyright Clearance Center Inc., 222 Rosewood Drive, Danvers MA 01923, USA; e-mail: info@copyright.com; Copyright Licensing Agency, 90 Tottenham Court Road, London W1P OLP, UK; e-mail: cla@cla.co.uk. This authorization does not extend to any other kind of copying, by any means, in any form, and for any purpose other than private research use. 